\title{
Faktor-faktor yang Memengaruhi Non Performing Finance (NPF) pada Bank Umum Syariah di Indonesia Tahun 2003-2019
}

\section{Ghaniya Rizki Nuraliyah*}

Prodi Ilmu Ekonomi, Fakultas Ekonomi dan Bisnis, Universitas Islam Bandung, Indonesia.

*ganiarizkin@gmail.com

\begin{abstract}
Financing is one of the functions of the bank to make a profit. The risk of financing a bank is non-performing financing (NPF). This study aims to determine the factors that affect the NPF of Islamic Commercial Banks in Indonesia, the period 2003-2019. The research object in this study includes the rate of inflation, profit sharing, per capita income rate, and NPF. The type of research used is descriptive quantitative with a verification approach. The data used is secondary data, namely annual data from 2003-2019. Secondary data obtain the official publications of the website of the Financial Services Authority and the Central Statistics Agency using time series data. Data processing using the Eviews version 11.0 program with the Ordinary Least Square (OLS) method, statistical tests, and economic analysis. The results showed that the inflation rate, profit sharing, and the rate of income per capita did not influence the NPF. Based on the partial test, the inflation variable has a positive and significant effect on the NPF. The profit-sharing variable has a negative and significant influence on the NPF, and the variable rate of income per capita has a positive and significant effect on the NPF. Therefore, Islamic Commercial Banks should respond to the inflation shifting, maintain financing supervision to minimize the NPF rate.
\end{abstract}

Keywords: $N P F$, Inflation, Profit Sharing, Per capita Income Rate.

\begin{abstract}
Abstrak. Pembiayaan merupakan salah satu fungsi dari bank guna memperoleh keuntungan. Resiko dari pembiayaan suatu bank yaitu pembiayaan bermasalah (NPF). Penelitian ini bertujuan untuk mengetahui faktor-faktor yang mempengaruhi NPF pada Bank Umum Syariah di Indonesia, periode 2003-2019. Objek penelitian pada penelitian ini meliputi tingkat inflasi, bagi hasil, laju pendapatan perkapita, dan NPF. Jenis penelitian yang digunakan adalah deskriptif kuantitatif dengan pendekatan verifikatif. Data yang digunakan adalah data sekunder yaitu data tahunan dari 2003-2019. Data sekunder diperoleh dari publikasi resmi website Otoritas Jasa Keuangan dan Badan Pusat Statistik menggunakan data runtut waktu (time series). Pengolahan data menggunakan program Eviews versi 11.0 dengan metode Ordinary Least Square (OLS), dilakukan uji statistik dan analisis ekonomi. Hasil penelitian menunjukkan bahwa tingkat inflasi, bagi hasil, dan laju pendapatan perkapita secara bersama-sama tidak berpengaruh terhadap NPF. Berdasarkan pengujian secara parsial variabel inflasi berpengaruh positif dan signifikan terhadap NPF, variabel bagi hasil berpengaruh negatif dan signifikan terhadap NPF, dan variabel laju pendapatan perkapita berpengaruh positif dan signifikan terhadap NPF. Bank Umum Syariah perlu merespon perubahan kenaikan inflasi, perlu menjaga pengawasan pembiayaan agar dapat meminimalisasi tingkat NPF.
\end{abstract}

Kata Kunci: NPF, Inflasi, Bagi Hasil, Laju Pendapatan Perkapita. 


\section{A. Pendahuluan}

Salah satu fungsi dari bank yaitu menyalurkan pembiayaan kepada masyarakat guna memperoleh keuntungan. Akan tetapi, dalam menjalankan fungsi pembiayaan, bank juga mempunyai risiko yaitu pembiayaan yang macet. Hal tersebut dapat dipengaruhi oleh banyak faktor. Semakin banyak jumlah nasabah yang tidak mampu memenuhi kewajibannya (gagal bayar), maka tingkat kerugian yang ditanggung oleh pihak bank akan semakin besar. Salah satu indikator yang digunakan untuk mengukur tingkat pembiayaan bermasalah yaitu rasio NPF.

Batas aman dari NPF yaitu sebesar 5\% dari total kreditnya. Jika pembiayaan bermasalah tersebut melampaui batas, maka akan menjadi sebuah masalah serius yang akan mengganggu profitabilitas bank syariah. Semakin tinggi tingkat NPF maka semakin tinggi risiko pembiayaan yang akan ditanggung oleh pihak bank. Akibat tingginya NPF bank harus menyediakan cadangan yang lebih besar, sehingga akan mengurangi cadangan modal yang dimiliki oleh bank.

Nilai NPF selama 10 tahun mulai dari periode 2003 sampai dengan 2019. Pada tahun 2006 menunjukan nilai NPF tertinggi selama 10 tahun tersebut (2003-2013) yaitu masingmasing menunjukan nilai 4,75\% lebih tinggi 1,93\% dari tahun sebelumnya. Kondisi seperti itu mengindikasikan situasi yang masih aman bagi Bank Umum Syariah, sebab idealnya NPF suatu lembaga keuangan bank syariah memiliki persentase NPF dibawah 5\%.

Nilai NPF yang paling rendah selama 10 tahun yaitu pada tahun 2012 sebesar 2,22\% atau turun $0,30 \%$ dari tahun 2011. Tinggi atau rendahnya tingkat NPF pada Bank Umum Syariah diakibatkan oleh beberapa faktor (multifactor) yang termasuk pada indikator-indikator makroekonomi seperti Inflasi dan Laju Pendapatan Perkapita, serta tingkat bagi hasil yang merupakan salah satu faktor internal Bank yang mampu mempengaruhi tingkat NPF tersebut.

Inflasi terjadi diindikasikan dengan naiknya harga barang dan jasa pada umumnya yang berlangsung secara terus menerus. Jika harga barang dan jasa di dalam negeri meningkat, maka inflasi mengalami kenaikan. Naiknya harga barang dan jasa tersebut menyebabkan turunnya nilai uang (Hasyim, 2016). Naiknya inflasi akan menyebabkan menurunnya pendapatan riil masyarakat sehingga daya beli masyarakat turun termasuk kemampuannya untuk membayar cicilan hutangnya.

Rasio inflasi selama 10 tahun cenderung rendah karena $<10 \%$. Selama 10 tahun, angka tertinggi tampak pada tahun 2007 yaitu sebesar 6,60\%. Seiring dengan tingginya persentase inflasi, rasio NPF menunjukan keadaan yang sebaliknya yaitu naik sebesar $1,93 \%$ menjadi 4,75\% pada tahun 2006. Sehingga, kondisi ini menggambarkan pada saat nilai inflasi tinggi maka akan terjadi perubahan tingkat NPF di Bank Umum Syariah menjadi lebih tinggi. Karena, tinggi atau rendahnya tingkat inflasi mengindikasikan adanya ketidakstabilan ekonomi makro akibat adanya kenaikan harga-harga pada suatu komoditas yang tidak diiringi purchasing power masyarakat.

Menurut Lisanti (2016) rate of profit atau margin bagi hasil diperoleh dari perdagangan atau industri sebagai selisih antara penerimaan dari penjualan dan biaya-biaya. Margin bagi hasil adalah besar bagi hasil usaha yang diberikan pihak bank syariah terhadap nasabah. Bagi hasil yang diberikan bank kepada nasabah bervariasi disesuaikan keuntungan yang didapatkan pihak bank, kemudian dibagi berdasarkan persentase yang disepakati pada akad perjanjian.

Penentuan bagi hasil (rate of profit) memengaruhi pendapatan yang diterima oleh masyarakat, sehingga tingkat bagi hasil yang fluktuatif akan menciptakan ketidakstabilan pendapatan masyarakat yang akan berdampak pada kemampuan debitur untuk memenuhi kewajibannya kepada pihak bank.

Nilai dari tingkat bagi hasil dan NPF pada periode 2003-2013 tampak nilai NPF yang fluktuatif dengan diiringi persentase pembiayaan bagi hasil pada Bank Umum Syariah. Tingkat bagi hasil tertinggi pada Bank Umum Syariah tampak pada tahun 2007 yang diiringi dengan turunnya rasio NPF sebesar $0,70 \%$ dari tahun 2006. Hal ini diakibatkan oleh meningkatnya penerimaan pembiayaan yang diperoleh perbankan, sehingga tingkat bagi hasil bank naik dan NPF bank menurun. Hal ini mengindikasikan hubungan antara NPF dan Bagi Hasil pada Bank Umum Syariah, yaitu semakin tinggi bagi hasil yang diberikan lembaga keuangan bank syariah maka akan menekan NPF pada bank tersebut. Hal ini dikarenakan kondisi tersebut menunjukan perolehan keuntungan lembaga keuangan bank yang tinggi akibat diperolehnya pendapatan 
melalui angsuran kredit nasabah.

Pendapatan perkapita diperoleh dari pendapatan nasional pada tahun tertentu dibagi dengan jumlah penduduk suatu Negara pada tahun tersebut. Laju pertumbuhan pendapatan perkapita dapat mengindikasikan kondisi perekonomian masyarakat.

Naik atau turunnya tingkat laju pendapatan perkapita akan berdampak pada kemampuan pembayaran seseorang terhadap kewajibannya yang termasuk pada pengeluaran atau kegiatan konsumsi suatu rumah tangga. tingkat NPF dan laju pendapatan perkapita yang fluktuatif. Tingkat laju pendapatan perkapita dalam penelitian ini diindikasikan melalui rasio Laju Pertumbuhan Pendapatan Domestik Bruto (PDB) perkapita. Nilai laju pendapatan perkapita yang tertinggi tampak pada tahun 2007 yaitu 4,80\%, nilai tersebut lebih tinggi $0,26 \%$ dari tahun sebelumnya. Seiring dengan tingginya laju pendapatan perkapita pada tahun 2007 , diikuti dengan penurunan NPF. Artinya, semakin tinggi laju pendapatan perkapita masyarakat maka semakin menurun NPF Bank Umum Syariah. Karena, ketika laju pendapatan perkapita naik timbul kemampuan untuk melakukan pembayaran angsuran (ability to pay).

Berdasarkan latar belakang yang telah diuraikan, maka tujuan penelitian untuk mengidentifikasi dan menganalisis:

1. Pengaruh inflasi, tingkat bagi hasil, dan laju pendapatan perkapita terhadap NPF pada Bank Umum Syariah di Indonesia tahun 2003-2019;

2. Besar pengaruh dari inflasi, tingkat bagi hasil, dan laju pendapatan perkapita terhadap NPF pada Bank Umum Syariah di Indonesia tahun 2003-2019.

\section{B. Metodologi Penelitian}

Jenis penelitian yang digunakan adalah deskriptif kuantitatif dengan pendekatan verifikatif. Data yang digunakan adalah data sekunder yaitu data tahunan dari 2003-2019. Data sekunder diperoleh dari publikasi resmi website Otoritas Jasa Keuangan, Bank Indonesia dan Badan Pusat Statistik menggunakan data runtut waktu (time series). Pengolahan data menggunakan program Eviews versi 11.0 dengan metode Ordinary Least Square (OLS), dilakukan pengujian asumsi klasik (Multikolinear, Autokorelasi, Heteroskedastis, dan Normalitas) dan uji statistik serta dilakukan analisis ekonomi.

\section{Hasil Penelitian dan Pembahasan}

Pengaruh Inflasi terhadap NPF pada Bank Umum Syariah di Indonesia

Berdasarkan hasil pengolahan data yang dilakukan diperoleh hasil bahwa:

Tabel 1. Pengaruh Inflasi terhadap NPF pada Bank Umum Syariah di Indonesia

\begin{tabular}{llll}
\hline Variable & $\mathbf{t}_{\text {hitung }}$ & $\mathbf{t}_{\text {tabel }}$ & Prob \\
\hline INFLASI & 1.1165 & 0.69383 & 0.044 \\
\hline
\end{tabular}

Sumber: Hasil Pengolahan Data, 2021

Pada Tabel 1 tampak inflasi berpengaruh positif terhadap NPF pada Bank Umum Syariah di Indonesia secara parsial. Inflasi ini memiliki koefisien sebesar 0.241587 yang artinya jika inflasi mengalami kenaikan sebesar 1\% maka akan meningkatkan NPF sebesar 0.241587 ataupun sebaliknya, apabila inflasi turun sebesar 1\% maka NPF akan turun sebesar 0.241587.

Hasil ini relevan dengan konsep teori inflasi, inflasi adalah suatu keadaan yang mengindikasikan semakin melemahnya daya beli yang diikuti dengan semakin merosotnya nilai riil (intrinsik) mata uang suatu. Inflasi ini dapat terjadi karena cost push inflation yaitu kondisi penurunan daya beli akibat kenaikan harga bahan baku atau material. Sehingga, ketika harga bahan baku meningkat maka biaya produksi yang dikeluarkan oleh suatu perusahaan akan mengalami peningkatan pula sehingga hal ini akan berdampak pada harga jual suatu produk. Sementara, kenaikan harga ini tidak diikuti dengan kenaikan daya beli masyarakat. 
Jika dikaitkan dengan NPF pada Bank Umum Syariah di Indonesia, kondisi inflasi tersebut akan mempengaruhi tinggi atau rendahnya NPF, karena menurut, bahwa NPF merupakan suatu keadaan dimana nasabah sudah tidak sanggup membayar sebagian atau seluruh kewajibannya kepada bank seperti yang telah diperjanjikan. Hasil penelitian yang diperoleh sesuai dengan hasil penelitian dari yang menyatakan bahwa variabel inflasi berpengaruh positif dan tidak signifikan terhadap NPF.

Adapun penelitian lain yang memperoleh hasil yang sama yaitu, variabel inflasi berpengaruh positif dan signifikan terhadap NPF, karena ketika inflasi mengalami kenaikan akan mengakibatkan turunnya daya beli masyarakat sehingga kegiatan konsumsi produk akan berkurang, hal ini menyebabkan turunnya profit perusahaan yang membuat perusahaan mengalami penurunan kemampuan dalam membayar angsurannya. Disisi lain, inflasi juga dapat menurunkan disposable income masyarakat sehingga kapabilitas masyarakat untuk membayar angsuran akan berkurang.

\section{Pengaruh Bagi Hasil terhadap NPF pada Bank Umum Syariah di Indonesia}

Berdasarkan hasil pengolahan data yang dilakukan diperoleh hasil bahwa :

Tabel 2. Pengaruh Bagi Hasil terhadap NPF pada Bank Umum Syariah di Indonesia

\begin{tabular}{lccc}
\hline Variable & $\mathbf{t}_{\text {hitung }}$ & $\mathbf{t}_{\text {tabel }}$ & Prob \\
\hline BAGIHASIL & 1.6037 & 0.69383 & 0.032
\end{tabular}

Sumber: Hasil Pengolahan Data, 2021

Pada Tabel 2 variabel bagi hasil berpengaruh negatif terhadap NPF pada Bank Umum Syariah di Indonesia secara parsial. Variabel bagi hasil ini memiliki koefisien sebesar -0.12963 yang artinya jika bagi hasil yang diberikan Bank Umum Syariah mengalami kenaikan sebesar $1 \%$ maka akan menurunkan NPF sebesar 0.12963 ataupun sebaliknya, apabila bagi hasil mengalami penurunan sebesar $1 \%$ maka NPF akan naik sebesar 0.12963. Jadi, tanda negatif pada koefisien bagi hasil ini menunjukan hubungan berbalik arah antara bagi hasil dengan NPF suatu Bank Umum Syariah.

Hasil ini relevan dengan konsep teori bagi hasil dari Sjahdeini (2014) adalah pengelola mengelola dana-dana tersebut dalam sistem yang dikenal dengan sistem pool of fund (penghimpunan dana), selanjutnya pengelola akan menginvestasikan dana-dana tersebut kedalam proyek atau usaha-usaha yang layak dan menguntungkan serta memenuhi semua aspek syariah. Ketika suatu bank berhasil menghimpun sejumlah dana, maka kegiatan jasa perbankan dapat berjalan misalnya dengan memberikan pembiayaan kepada nasabah sebagai bentuk pengelolaan dana yang berhasil dihimpun. Artinya, semakin besar dana yang dihimpun untuk dikelola oleh bank maka akan semakin besar dana yang digunakan untuk pembiayaan. Hal ini disebabkan untuk menghindari terjadinya pengumpulan dana, sehingga bank tetap melakukan kebijakan pemberian pembiayaan dengan prosedur berhati-hati untuk menghindari terjadinya risiko NPF.

Begitupun jumlah pembiayaan naik, maka Bagi Hasil akan naik. sehingga, korelasi tidak langsung antara hubungan bagi hasil dengan NPF mengatakan: bagi hasil naik maka NPF turun, atau berlaku sebaliknya [9]. Hasil penelitian lain yang relevan yaitu dari Sundarwati (2019) yaitu pembiayaan bagi hasil berpengaruh tidak signifikan terhadap NPF. Begitu juga dengan hasil penelitian Harahap (2016) yang menyatakan bahwa variabel margin bagi hasil berpengaruh signifikan terhadap NPF.

\section{Pengaruh Inflasi terhadap NPF pada Bank Umum Syariah di Indonesia}

Berdasarkan hasil pengolahan data yang dilakukan diperoleh hasil bahwa :

Tabel 3. Pengaruh Laju Pendapatan Perkapita terhadap NPF pada Bank Umum Syariah di Indonesia 


\begin{tabular}{llll}
\hline Variable & $\mathbf{t}_{\text {hitung }}$ & $\mathbf{t}_{\text {tabel }}$ & Prob \\
\hline PDB & 1.2404 & 0.69383 & 0.036
\end{tabular}

Sumber: Hasil Pengolahan Data, 2021

Berdasarkan Tabel 3 laju pendapatan perkapita berpengaruh positif terhadap NPF pada Bank Umum Syariah di Indonesia secara parsial. Variabel laju pendapatan perkapita ini memiliki koefisien sebesar 0.415691 yang artinya jika laju pendapatan perkapita masyarakat mengalami kenaikan sebesar 1\% maka akan meningkatkan NPF sebesar 0.415691 ataupun sebaliknya, apabila bagi hasil mengalami kenaikan sebesar $1 \%$ maka NPF akan naik sebesar 0.415691 .

Hasil ini relevan dengan konsep teori pendapatan perkapita menurut Suleman \& Ahdiyat M (2020) yaitu pendapatan perkapita suatu negara merupakan tolak ukur kemajuan dari negara tersebut, apabila laju pendapatan perkapita suatu negara rendah dapat dipastikan mekanisme ekonomi masyarakat di negara tersebut mengalami penurunan atau bisa jadi stagnan, dan begitu pula sebaliknya. Naik atau turunnya tingkat laju pendapatan perkapita akan berdampak pada tinggi atau rendahnya tingkat NPF di Bank Umum Syariah. Karena pada saat tingkat laju pendapatan perkapita naik maka kemampuan bayar nasabah juga menjadi tinggi sehingga nilai NPF di Bank Umum Syariah menjadi rendah. Sedangkan ketika tingkat laju pendapatan perkapita masyarakatnya menurun maka kemampuan bayar nasabah menjadi rendah karena total pendapatan tersebut habis digunakan dalam memenuhi konsumsi sehari-hari, dampaknya nilai NPF di Bank Umum Syariah menjadi tinggi.

Hal ini sesuai dengan penelitian yang dilakukan oleh yang menyebutkan bahwa Damayanti (2019) variabel laju pendapatan perkapita memiliki pengaruh yang positif dan signifikan terhadap tingkat NPF. Kemudian, hasil yang sama juga tampak pada hasil penelitian dari Wijoyo (2016) yaitu laju pertumbuhan PDRB perkapita memiliki pengaruh terhadap NPF [15]. Hasil penelitian lainnya juga menyatakan bahwa variabel laju PDB perkapita berpengaruh tidak signifikan terhadap NPF.

\section{Kesimpulan}

Berdasarkan pembahasan dalam penelitian ini, peneliti menyimpulkan beberapa hasil penelitian sebagai berikut:

1. Variabel inflasi, bagi hasil, dan laju pendapatan perkapita secara simultan tidak berpengaruh signifikan terhadap NPF pada bank umum syariah di Indonesia periode 2003-2019. Artinya, ketiga faktor tersebut tidak memberikan dampak bagi tingkat NPF suatu bank syariah secara bersama-sama. Tetapi, berdasarkan hasil pengujian secara parsial (uji-t) inflasi berpengaruh positif signifikan terhadap NPF artinya, ketika inflasi naik maka NPF pun akan ikut naik sebab inflasi mencerminkan kemampuan daya beli masyarakat suatu negara. Bagi hasil berpengaruh negatif terhadap NPF, hal ini dapat terjadi karena ketika suatu bank syariah memperoleh pendapatan yang tinggi maka kemampuan bagi hasilnya akan tinggi yang berarti NPF bank tersebut turun. Dan laju pendapatan perkapita berpengaruh positif signifikan terhadap NPF, artinya ketika laju pendapatan perkapita mengalami kenaikan maka dapat meningkatkan rasio NPF karena meskipun daya beli masyarakat betambah seiring dengan pertambahan laju pendapatan perkapita tetapi terdapat faktor internal lainnya.

2. Berdasarkan hasil perhitungan koefisien determinasi (R2) diketahui bahwa besarnya pengaruh inflasi, bagi hasil, dan laju pendapatan perkapita bank umum syariah adalah sebesar 0,317189, artinya seluruh variasi variabel bebas (inflasi, bagi hasil, dan laju pendapatan perkapita) mampu menjelaskan variasi pada NPF bank umum syariah adalah sebesar $31,7189 \%$, sedangkan sisanya sebesar $68.281 \%$ dipengaruhi oleh variabel lain yang tidak terdapat pada penelitian ini misalnya nilai kurs, ROA, dan lainnya. menurut tabel kriteria Guilford. Hal ini berarti bahwa siswa SMAN 12 Kota Bandung dalam mengambil keputusan untuk menggunakan produk air mineral merek Le Minerale didasarkan pada iklan yang responden lihat di berbagai media promosi. Siswa SMAN 12 Kota Bandung menyatakan ingin menggunakan Le Minerale ketika merasa haus 
sekaligus ingin membandingkan dengan produk air mineral merek lain.

\section{Acknowledge}

Penulis mengucapkan terimakasih yang sebesar-besarnya kepada pihak-pihak yang telah membantu dalam menyelesaikan karya ilmiah ini. Terkhusus untuk Bapak dan Ibu dosen pembimbing yang telah membantu memberikan saran dalam penyusunan karya ilmiah ini. Semoga karya ilmiah ini dapat bermanfaat bagi para pembaca dan dapat membantu bagi penelitipeneliti selanjutnya. Terimakasih untuk Prodi Ekonomi Pembangunan/Ilmu Ekonomi yang telah menjadi tempat bagi penulis dalam menimba ilmu.

\section{Daftar Pustaka}

[1] H. Rafsanjani, R. Amin, and A. Mujib, "Faktor-faktor yang Mempengaruhi Non Performing Financing," J. Masharif al-Syariah J. Ekon. dan Perbank. Syariah, vol. 2, no. 2, Nov. 2017.

[2] M. Syaifullah, K. Anwari, M. Akmal, and Fachrurrazi, Kinerja Keuangan Bank Syariah. Depok: PT. Rajagrafindo Persada, 2020.

[3] A. . Suleman and Ahdiyat M, Ekonomi Makro. Medan: Yayasan Kita Menulis, 2020.

[4] M. Mutamimah and S. N. Z. Chasanah, "Analisis Eksternal Dan Internal Dalam Menentukan Non Performing Financing Bank Umum Syariah Di Indonesia,” J. Bisnis dan Ekon., vol. 19, no. $1,2012$.

[5] T. . Usanti and A. Shomad, Hukum Perbankan , 1st ed. Jakarta: Kencana, 2016.

[6] Sattar and S. K. Wijayanti, Buku Ajar Teori Ekonomi Makro, 1st ed. 2018.

[7] B. P. Cahyono, S. M. Thawil, and Sohirin, "Dampak Pertumbuhan PDB Perkapita, Pengeluaran Rumah Tangga Perkapita, Perdagangan Terbuka dan Laju Populasi Perkotaan Terhadap Konsumsi Energi Akhir Perumahan," Media Trend, vol. 15, no. 1, pp. 83-96, Mar. 2020.

[8] Z. Wangsawidjaja, Pembiayaan bank Syariah. Jakarta: PT. Gramedia Pustaka Utama, 2013.

[9] K. Marella and V. Wahibur, "Analisis Faktor-Faktor Yang Mempengaruhi Non Performing Financing Pada Perbankan Syariah Di Indonesia Tahun 2011-2016," Equilib. J. Ekon. Syariah, vol. 5, no. 2, pp. 306-319, 2017.

[10] Y. Muqorrobin, "Analisis Faktor-Faktor Eksternal yang Mempengaruhi Non Performing Finance (Npf) pada Bank Umum Syariah (Periode 2009 Q1-2018 Q4)," Ponorogo, Nov. 2019.

[11] S. R. Sjahdeini, Perbankan Syariah , 3rd ed. Jakarta: Prenada Media Group, 2014.

[12] A. M. Harahap, "Faktor-faktor Yang Mempengaruhi Non Performing Financing Pada Bank Syariah," Medan, 2016.

[13] N. S. Purba and A. Darmawan, "Pengaruh Pertumbuhan Produk Domestik Bruto Dan Inflasi Terhadap Non Performing Finance Bank Syariah (Studi Pada Bank Umum Syariah Di Indonesia Periode 2014-2016),” J. Adm. Bisnis, vol. 61, no. 2, pp. 161-167, 2018.

[14] T. Damayanti, "Pengaruh Produk DOmestik Bruti (PDB), Inflasi, Dan Financing To Deposit Ratio (FDR) terhadap Nn Performing Financing (NPF) pada Bank Rakyat Indonesia Syariah," Purwokerto, 2019.

[15] S. Wijoyo, "Analisis Faktor Makroekonomi Dan Kondisi Spesifik Bank Syariah Terhadap Non Performing Finance (Studi Pada Bank Umum Syariah Dan Unit Usaha Syariah Yang Ada Di Indonesia Periode 2010:1-2015:12)," Yogyakarta, Sep. 2016. 